\title{
PENGARUH OPTIMASI LAMA FERMENTASI TERHADAP KARAKTERISTIK KOMBUCHA DAUN TUA KOPI ROBUSTA DAMPIT METODE OKSIDATIF DAN NON-OKSIDATIF
}

\section{Effect Of Fermentation Time Optimaztion On Kombucha Characteristics From Old Leaves Of Robusta Coffe From Dampit With Oxidative And Non-Oxidative Methods}

\author{
Galuh Sasanti Prajati Kusuma*, Kiki Fibrianto \\ Jurusan Teknologi Hasil Pertanian, FTP Universitas Brawijaya Malang \\ Jl. Veteran, Malang 65145 \\ *Penulis Korespondensi, Email: galuhsasanti08@gmail.com
}

\begin{abstract}
ABSTRAK
Optimasi lama fermentasi menggunakan Respon Surface Method dengan rancangan One Factor. Variabel bebas yang digunakan adalah lama fermentasi pada kombucha $\left(X_{1}\right)$ dan respon yang dioptimasi adalah aktivitas antioksidan $\left(\mathrm{Y}_{1}\right)$. Kombucha teh daun tua kopi yang optimum akan dianalisis fisik, kimia dan organoleptik. Penelitian ini menggunakan rancangan percobaan tersarang (nested). Data yang diperoleh kemudian dianalisis dengan menggunakan analisis ragam (ANOVA) dengan selang kepercayaan 95\% dan diuji lanjut dengan Uji Fisher. Hasil optimasi menunjukkan lama fermentasi yang menghasilkan $\mathrm{IC}_{50}$ optimum adalah 0 hari. Pengujian karakteristik produk menunjukkan pada kombucha daun tua kopi memberikan pengaruh nyata terhadap aktivitas antioksidan $\left(\mathrm{IC}_{50}\right)$, total fenol, kadar tanin, total gula, dan nilai $\mathrm{pH}$. Hasil uji organoleptik menunjukkan perbedaan nyata terhadap 7 atribut. Hasil uji hedonik menunjukkan perbedaan signifikan pada semua parameter. Hasil uji penerimaan menunjukkan semua sampel kombucha dapat diterima panelis.
\end{abstract}

Kata kunci: Daun Kopi, Lama Fermentasi, Optimasi, Teh Kombucha

\section{ABSTRACT}

Fermentation time optimization using Response Surface Method with One Factor. The independent variable used was the duration of fermentation in Kombucha $\left(\mathrm{X}_{1}\right)$ and the response to be optimized was antioxidant activity $\left(Y_{1}\right)$. The optimum kombucha tea leaves old coffee will be analyzed physically, chemically, and organoleptically. This study useed a nested trial design. Data obtained were analyzed by ANOVA with a $95 \%$ confidence level. The results of fermentation duration optimization showed that the fermentation time for 0 days resulted in the optimum $I_{50}$ values. The test results kombucha showed significant differences in $I_{50}$, total phenol, tannin levels, total sugar, $\mathrm{pH}$ value. The results of testing of organoleptic kombucha showed significant differences in the 7 attributes. The hedonic test results showed significant differences in all parameters. The acceptance test results showed that all samples of kombucha can be accepted by panelists.

Keywords: Coffee Leaves, Duration of Fermentation, Optimization, Kombucha Tea

\section{PENDAHULUAN}

Kombucha merupakan minuman salah satu olahan fermentasi teh yaitu dengan penambahan starter kombucha yang biasa disebut dengan SCOBY yang terdiri dari bakteri dan khamir. Kombucha memiliki manfaat dalam kesehatan tubuh. Selama proses fermentasi kombucha, bakteri dan khamir melakukan metabolisme terhadap sukrosa dan menghasilkan sejumlah asam-asam. Selama ini pembuatan kombucha dengan menggunakan teh hitam dan 
teh hijau dari daun (Camellia sinensis). Banyak penelitian mengenai kombucha dengan berbagai jenis daun. Salah satu daun pengganti daun teh Camellia sinensis dalam pembuatan kombucha adalah daun kopi. Daun kopi biasanya hanya dimanfaatkan untuk pembuatan teh dan tidak jarang juga dipangkas sebagai bahan pupuk untuk tanaman kopi. Sehingga perlu pemanfaatan lebih lanjut pada olahan daun kopi. Tujuan dari penelitian ini untuk mengetahui karakteristik kombucha teh daun kopi yang dibuat dengan metode oksidatif yang diolah dengan pelayuan dan non-oksidatif yang diolah tanpa pelayuan pada lama fermentasi optimum.

\title{
BAHAN DAN METODE
}

\section{Bahan}

Bahan-bahan yang digunakan dalam penelitian ini adalah daun tua kopi robusta yang diperoleh dari kebun kopi Kelompok Tani "Tani Harapan" Kecamatan Dampit, Kabupaten Malang. Daun teh yang diperoleh dari Kebun Teh Wonosari, Malang. Starter cair kombucha merk "Indokombucha", DPPH 0,2 mM, $\mathrm{Na}_{2} \mathrm{CO}_{3}$, sukrosa, aquades, asam galat, Pb-asetat, $\mathrm{Na}$ oksalat, asam oksalat, methanol, indikator $\mathrm{PP}, \mathrm{CaCO}_{3}$, anthrone, folin ciocalteau, $\mathrm{NaOH} 0,1$ $\mathrm{N}$, alkohol 70\%, pepton, plate count agar, spirtus, buffer $\mathrm{pH} 4$ dan buffer $\mathrm{pH} 7$.

\begin{abstract}
Alat
Alat-alat yang digunakan dalam penelitian ini adalah cabinet dryer, kompor listrik, toples kaca, saringan teh, kain saring penutup jar, timbangan analitik, pengaduk kaca, alumunium foil, beaker glass, termometer, pH meter, desikator, gelas ukur, oven listrik, pipet tetes, pipet ukur, buret dan statif, vortex, labu takar, tabung reaksi, spektrofotometer uv-vis, kertas saring, dan color reader.
\end{abstract}

\section{Desain Penelitian}

Optimasi lama fermentasi menggunakan metode Response Surface Method dengan rancangan one factor dengan menggunakan satu respon pada Design Expert 7, dimana faktornya adalah lama fermentasi selama 0-21 hari dan responnya adalah aktivitas antioksidan $\left(\mathrm{IC}_{50}\right)$. Hasil solusi yang disarankan selanjutnya diverifikasi dan dilanjutkkan dengan paired t-test menggunakan Minitab 17. Selanjutnya dilakukan pengujian fisik, kimia, dan organoleptik terhadap produk kombucha daun kopi dan kombucha daun teh sebagai sampel kontrol menggunakan rancangan percobaan tersarang (nested) dangan faktor mayor adalah jenis daun dan faktor minor adalah jenis pengolahan daun. Data dianalisis menggunakan Minitab 17 dengan metode analisis ragam (ANOVA) dilanjut dengan uji lanjut Fisher dengan selang kepercayaan 95\%.

\section{Tahapan Penelitian}

Penelitian dilaksanakan dengan membuat teh daun kopi dari dua jenis daun kopi yang diolah dengan metode oksidatif dan non-oksidatif untuk dijadikan kombucha. Teh daun kopi diseduh menggunakan metode tubruk menggunakan air dengan suhu $70^{\circ} \mathrm{C}$ selama 10 menit dengan perbandingan teh daun kopi $1 \%$ dari air. Pada seduhan daun kopi ditambahkan gula pasir sebanyak $10 \%$ dari larutan kemudian disaring kedalam jar kaca. Setelah itu didinginkan hingga mencapai suhu $25^{\circ} \mathrm{C}$ dan ditambahkan starter cair sebanyak $10 \%$ dari larutan. Jar kaca ditutup menggunakan kain dan diikat karet lalu difermentasi pada suhu ruang. Fermentasi dilakukan sesuai level waktu fermentasi yang dirancang oleh Design Expert 7, yaitu 0 hari, 0 hari, 5 hari, 11 hari, 16 hari, 21 hari, dan 21 hari. Selama level waktu fermentasi dilakukan pengukuran respon yaitu uji aktivitas antioksidan $\left(\mathrm{IC}_{50}\right)$ pada sampel. Hasil respon yang diperoleh selanjutnya dilakukan optimasi pada Design Expert 7 dan dihasilkan solusi. Selanjutnya dilakukan verifikasi pada solusi yang diperoleh dari Design Expert 7. Produk kombucha dengan respon optimum selanjutnya dilakukan uji fisik, kimia, dan organoleptik 
pada produk kombucha daun kopi sebagai sampel uji dan kombucha teh sebagai sampel kontrol untuk membandingkan karakteristik kombucha daun kopi dan kombucha daun teh.

\section{Prosedur Analisis}

Analisis dilakukan pada 4 tahap, yaitu bubuk, seduhan, respon aktivitas antioksidan produk. Analisis yang dilakukan adalah analisis aktivitas antioksidan $\left(\mathrm{IC}_{50}\right)$, analisis total asam, analisis total fenol, analisis kadar tanin, analisis total gula, analisis $\mathrm{pH}$, analisis warna, dan analisis total mikroba serta uji organoleptik.

\section{HASIL DAN PEMBAHASAN}

\section{Analisis Bahan Baku}

Tabel 1. Karakteristik Bahan Baku

\begin{tabular}{lcccccc}
\hline \multicolumn{1}{c}{ Komponen } & \multicolumn{2}{c}{ Hasil Analisis } & \multicolumn{2}{c}{ Literatur } \\
\cline { 2 - 7 } & $\begin{array}{c}\text { Kopi Non- } \\
\text { oksidatif }\end{array}$ & $\begin{array}{c}\text { Kopi } \\
\text { Oksidatif }\end{array}$ & $\begin{array}{c}\text { Teh Non- } \\
\text { oksidatif }\end{array}$ & $\begin{array}{c}\text { Teh } \\
\text { Oksidatif }\end{array}$ & $\begin{array}{c}\text { Teh } \\
\text { hijau }\end{array}$ & $\begin{array}{c}\text { Teh } \\
\text { hitam }\end{array}$ \\
\hline IC50 $(\mathrm{ppm})$ & $36.04 \pm 0.11$ & $45.48 \pm 0.05$ & $48.05 \pm 0.02$ & $50.12 \pm 0.19$ & $57.52^{\mathrm{a}}$ & $66.75^{\mathrm{a}}$ \\
\hline Total asam (\%) & $0.19 \pm 0.06$ & $0.19 \pm 0.06$ & $0.23 \pm 0.04$ & $0.17 \pm 0.07$ & - & - \\
\hline $\begin{array}{l}\text { Total fenol (mg } \\
\text { GAE/L) }\end{array}$ & $86.78 \pm 0.14$ & $52.32 \pm 0.05$ & $29.64 \pm 0.00$ & $10.55 \pm 0.05$ & - & - \\
\hline $\begin{array}{l}\text { Kadar tanin (mg } \\
\text { TAE/L) }\end{array}$ & $44.15 \pm 0.25$ & $27.12 \pm 0.14$ & $32.43 \pm 0.25$ & $15.76 \pm 0.32$ & - & - \\
\hline Kadar air (\%) & $1.63 \pm 0.67$ & $1.40 \pm 0.67$ & $1.72 \pm 0.82$ & $1.76 \pm 0.78$ & $\begin{array}{c}\text { Maks. } \\
8^{\mathrm{b}}\end{array}$ & $\begin{array}{c}\text { Maks. } \\
8^{\mathrm{b}}\end{array}$ \\
\hline Total gula (\%) & $10.42 \pm 0.10$ & $7.06 \pm 0.27$ & $8.36 \pm 0.64$ & $6.36 \pm 0.37$ & - & -
\end{tabular}

Sumber : a. Wijana, 2017; b. SNI, 2014

Hasil aktivitas antioksidan $\left(\mathrm{IC}_{50}\right)$ bubuk daun kopi lebih tinggi dibandingkan dengan sampel kontrol bubuk teh Camellia sinensis. Perbedaan hasil analisis aktivitas antioksidan dengan literatur disebabkan karena adanya perbedaan proses pengeringan daun kopi dengan menggunakan tunnel dryer pada suhu $75^{\circ} \mathrm{C}$ selama 4 jam kemudian diblender selama 10 menit menjadi bubuk daun teh (Wijana et al., 2017). Hasil total asam pada daun teh nonoksidatif total asam lebih tinggi dibandingkan dengan daun teh oksidatif. Total asam pada buah semakin menurun disebabkan terjadinya reaksi oksidasi saat pengirisan menggunakan pisau dan penghancuran daging buah dengan blender (Winarno, 1997). Ditinjau dari perlakuan yang diberikan pada sampel daun, maka hal ini sesuai dengan pernyataan Winarno (1997), dimana bubuk daun yang diolah secara non-oksidatif memiliki total asam yang lebih tinggi dibandingkan dengan bubuk daun yang diolah secara oksidatif. Kandungan total fenol daun kopi non-oksidatif lebih tinggi dibandingkan dengan daun kopi oksidatif. Menurut Achakzai (2009), total fenol dapat menurun karena adanya proses pengeringan dan pelayuan yang dapat mengakibatkan rusaknya zat aktif yang terkandung dalam suatu bahan. Semakin lama waktu pelayuan, menunjukkan penurunan kandungan fenolik pada bahan karena kandungan fenolik teroksidasi oleh oksigen dari udara dengan bantuan enzim oksidase (Nasution dan Wachyuddin, 1985). Kadar tanin bubuk daun kopi non-oksidatif lebih tinggi dibandingkan dengan bubuk daun kopi oksidatif. Semakin tinggi kadar tanin, semakin tinggi kualitas bahan baku. Menurut Rohdiana (2007), bahwa proses oksidasi enzimatis dapat mengubah sebagian tanin menjadi senyawa turunan yaitu teaflavin dan tearubigin. Terbentuknya senyawa turunan tersebut maka kadar tanin dalam daun teh akan berkurang, sehingga kadar tanin teh hijau lebih tinggi dibandingkan dengan teh hitam. Kadar air bubuk teh hijau lebih tinggi dibandingkan dengan teh hitam. Hal ini disebabkan oleh ukuran produk akhir teh dan proses pengeringan yang berbeda, ukuran partikel teh hitam lebih kecil sehingga penguapan air bahan selama pengeringan lebih cepat sehingga kadar air produk lebih kecil (Wijana dkk., 2017). Total gula bubuk daun kopi non-oksidatif lebih tinggi dibandingkan dengan bubuk daun kopi oksidatif. Menurut Heldman (2012) proses penguapan air dapat mempengaruhi total gula pada bahan, jika penguapan semakin tinggi maka kadar air semakin 
turun sehingga presentase total gula semakin meningkat. Adanya penguapan air selama pemanasan menyebabkan kadar air menurun dan konsentrasi padatan akan meningkat (Agus, 2012).

\section{Optimasi Lama Fermentasi Terhadap $\mathbf{I C}_{50}$}

Tabel 2. Data Hasil Analisis Respon Aktivitas Antioksidan Kombucha Teh Daun Kopi NonOksidatif

\begin{tabular}{ccccc}
\hline Id & Run & $\begin{array}{c}\text { Variabel Kode } \\
\left(\mathbf{X}_{\mathbf{1}}\right)\end{array}$ & $\begin{array}{c}\text { Variabel Actual } \\
\begin{array}{c}\text { Lama Fermentasi } \\
(\text { hari) }\end{array}\end{array}$ & $\begin{array}{c}\text { Aktivitas Antioksidan } \\
\left(\mathbf{Y}_{\mathbf{1}}\right)\end{array}$ \\
\hline 1 & & & & \\
2 & 3 & -1.000 & 0 & 63.54 \\
3 & 5 & -1.000 & 0 & 62.09 \\
4 & 4 & -0.500 & 5 & 65.58 \\
5 & 6 & 0.000 & 11 & 75.87 \\
6 & 7 & 0.500 & 16 & 82.76 \\
7 & 1 & 1.000 & 21 & 89.24 \\
\hline
\end{tabular}

Tabel 3. Data Hasil Analisis Respon Aktivitas Antioksidan Kombucha Teh Daun Kopi Oksidatif

\begin{tabular}{|c|c|c|c|c|}
\hline Id & Run & $\begin{array}{c}\text { Variabel Kode } \\
\left(\mathrm{X}_{1}\right)\end{array}$ & $\begin{array}{l}\text { Variabel Actual } \\
\text { Lama Fermentasi } \\
\text { (hari) }\end{array}$ & $\begin{array}{c}\text { Respon } \\
\text { Aktivitas Antioksidan } \\
\left(\mathrm{Y}_{1}\right)\end{array}$ \\
\hline 1 & 3 & -1.000 & 0 & 63.95 \\
\hline 2 & 5 & -1.000 & 0 & 63.42 \\
\hline 3 & 4 & -0.500 & 5 & 79.38 \\
\hline 4 & 6 & 0.000 & 11 & 98.53 \\
\hline 5 & 7 & 0.500 & 16 & 112.14 \\
\hline 6 & 1 & 1.000 & 21 & 120.59 \\
\hline 7 & 2 & 1.000 & 21 & 119.19 \\
\hline
\end{tabular}

Penentuan respon optimum yaitu berdasarkan pemilihan model yang paling sesuai untuk evaluasi model dari sistem komputerisasi Design Expert 7. Penentuan model yang sesuai yaitu berdasarkan model urutan jumlah kuadrat (Sequential Model Sum of Squares), pengujian ketidaktepatan model (Lack of Fit Tests), dan ringkasan model statistik (Model Summary Statistics). berdasarkan hasil pemilihan model, model yang disarankan oleh Design Expert 7 adalah model linear untuk respon aktivitas antioksidan daun kopi non-oksidatif dan model cubic untuk respon aktivitas antioksidan daun kopi oksidatif.

Hasil optimasi Design Expert 7 memberikan solusi yang dipilih yaitu lama fermentasi yang menghasilkan nilai $I \mathrm{IC}_{50}$ sebesar $62.09 \mathrm{ppm}$ untuk kombucha daun tua kopi non-oksidatif dan 63.62 ppm untuk kombucha daun tua kopi oksidatif. Didapatkan hasil lama fermentasi yang menghsailkan $\mathrm{IC}_{50}$ optimum pada kedua sampel kombucha yaitu selama 0 hari. Selanjutnya dilakukan verifikasi terhadap nilai optimasi yang disarankan Design Expert 7.

\section{Analisis Produk}

\subsection{Aktivitas Antioksidan ( $\left.\mathrm{IC}_{50}\right)$}

Pada sampel kombucha teh daun kopi dan daun Camellia sinensis terjadi peningkatan nilai $\mathrm{IC}_{50}$. Nilai $\mathrm{IC}_{50}$ adalah bilangan yang menunjukkan kemampuan menghambat proses oksidasi sebesar $50 \%$. Semakin kecil nilai $I_{50}$, berarti semakin tinggi aktivitas antioksidan. Hasil penelitian menunjukkan bahwa aktivitas antioksidan seduhan menjadi kombucha terjadi penurunan akibat proses fermentasi disebabkan karena adanya perubahan nilai pH. Semakin lama proses fermentasi nilai $\mathrm{pH}$ teh kombucha akan semakin rendah. Hal tersebut akan berdampak pada terjadinya kerusakan fenol yang berperan sebagai antioksidan. Menurut 
Pratama (2015), antioksidan tidak stabil pada suasana asam, hal ini disebabkan karena adanya senyawa-senyawa yang memiliki gugus aktif yaitu gugus hidroksil yang dapat bersifat sebagai antiradikal bebas, dengan cara mendonorkan elektron yang tidak berpasangan kepada senyawa radikal sehingga radikal bebas menjadi stabil.

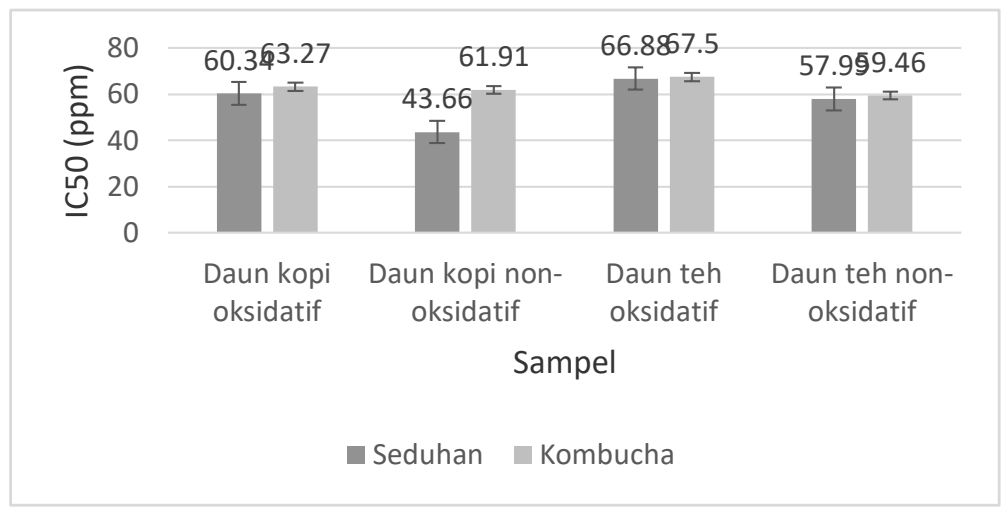

Gambar 1. Grafik Rerata Aktivitas Antioksidan Seduhan dan Kombucha

\subsection{Total Asam}

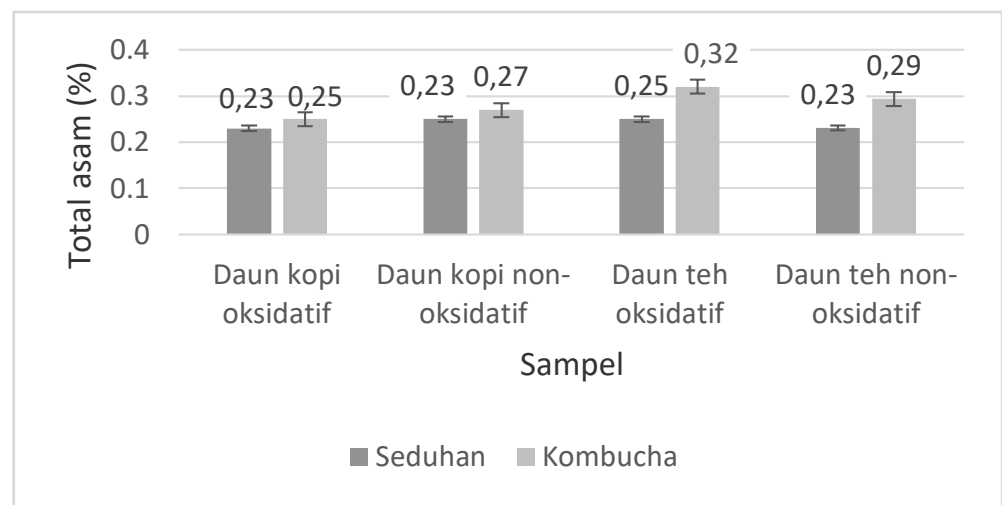

Gambar 2. Grafik Rerata Total Asam Seduhan dan Kombucha

Pada hasil analisis diketahui bahwa terjadi peningkatan total asam karena adanya penambahan gula pada seduhan yang telah ditambahkan starter dimana selama proses tersebut sukrosa akan dirombak menjadi glukosa dan fruktosa oleh bakteri dan khamir. Kemudian glukosa akan digunakan untuk membentuk alkohol dan asam-asam organik sehingga konsentrasi asam-asam organik meningkat dan total asam meningkat juga. Menurut Greenwalt et al., (1998) menyatakan bahwa selama proses fermentasi kombucha, khamir akan memecah sukrosa menjadi glukosa dan fruktosa.

\subsection{Total Fenol}

Pada hasil analisis diketahui bahwa terjadi penurunan total fenol akibat adanya pemanasan dengan suhu $100^{\circ} \mathrm{C}$ yang dapat mengakibatkan kerusakan komponen yang tidak tahan terhadap panas. Seperti penelitian sebelumnya Kettawan et al. (2011), menyatakan bahwa proses perebusan selama 2 menit pada suhu $100^{\circ} \mathrm{C}$ menurunkan total fenol. Besarnya total fenol berbanding lurus dengan nilai aktivitas antioksidan kombucha. Hal tersebut telah dijelaskan oleh Walter dan Marchesen (2011), bahwa semakin tinggi total fenol, maka aktivitas antioksidannya akan semakin tinggi pula. 
Pengaruh Optimasi Lama Fermentasi Terhadap Karakteristik - Kusuma, dkk Jurnal Pangan dan Agroindustri Vol.6 No.4: 87-97, Oktober 2018

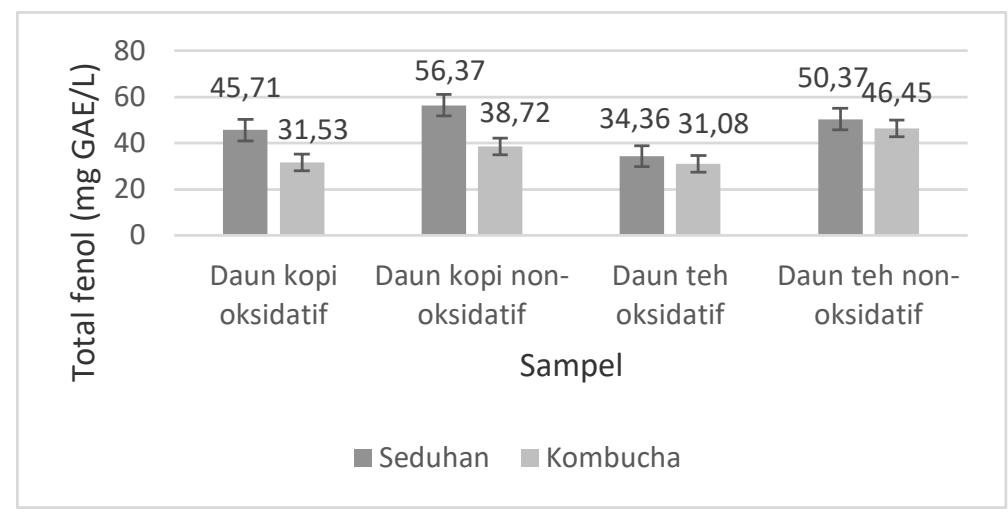

Gambar 3. Grafik Rerata Total Fenol Seduhan dan Kombucha

\subsection{Kadar Tanin}

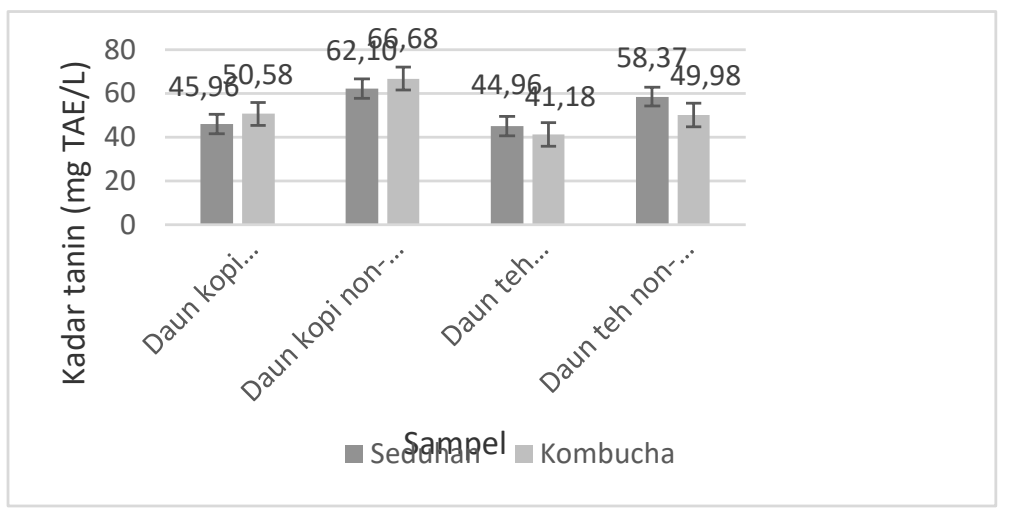

Gambar 4. Grafik Rerata Kadar Tanin Seduhan dan Kombucha

Pada hasil analisis diketahui bahwa terjadi peningkatan kadar tanin akibat adanya aktivitas bakteri Acetobacter xylinum yang dapat mempolimerisasikan tanin yang terkandung dalam kombucha sebagai media fermentasi tersebut. Tanin akan menyebabkan rasa sedikit sepat pada kombucha daun kopi. Rasa sepat yang timbul berasal dari senyawa tanin yang terkandung dalam kopi yang larut dalam air pada saat proses fermentasi berlangsung (Rahayu, 2012).

\subsection{Total Gula}

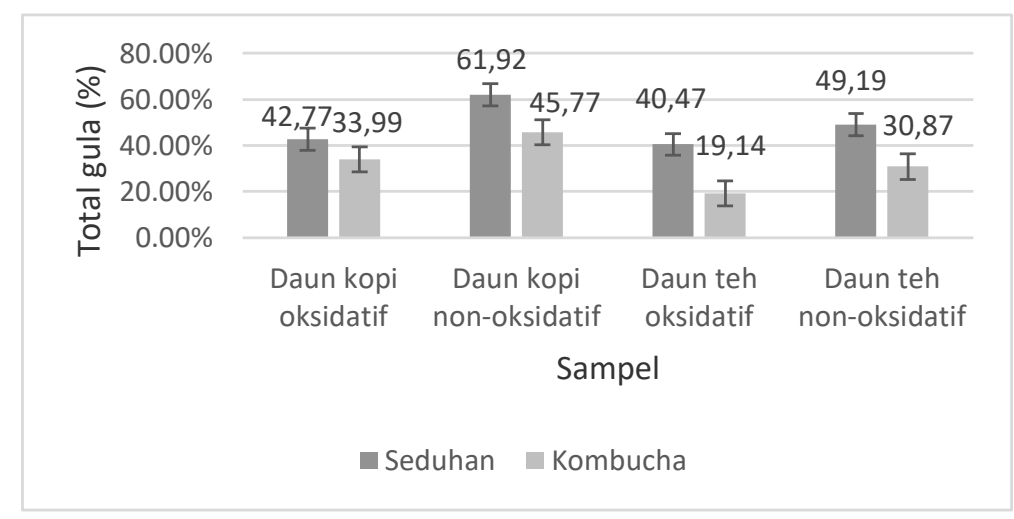

Gambar 5. Grafik Rerata Total Gula Seduhan dan Kombucha

Pada hasil analisis diketahui bahwa terjadi penurunan total gula akibat penambahan starter kombucha pada seduhan teh. Proses naik dan turunnya total gula dipengaruhi oleh 
bakteri Acetobacter xylinum dan khamir yang terdapat pada media. Penurunan total gula disebabkan oleh hidrolisis sukrosa menjadi glukosa oleh enzim invertase. Hidrolisis terjadi karena $\mathrm{pH}$ media sangat rendah dimana pada kondisi $\mathrm{pH}$ tersebut, sukrosa sangat mudah untuk dihidrolisis oleh enzim invertase (Apriyantono et al., 1989).

\section{$3.6 \mathrm{Uji} \mathrm{pH}$}

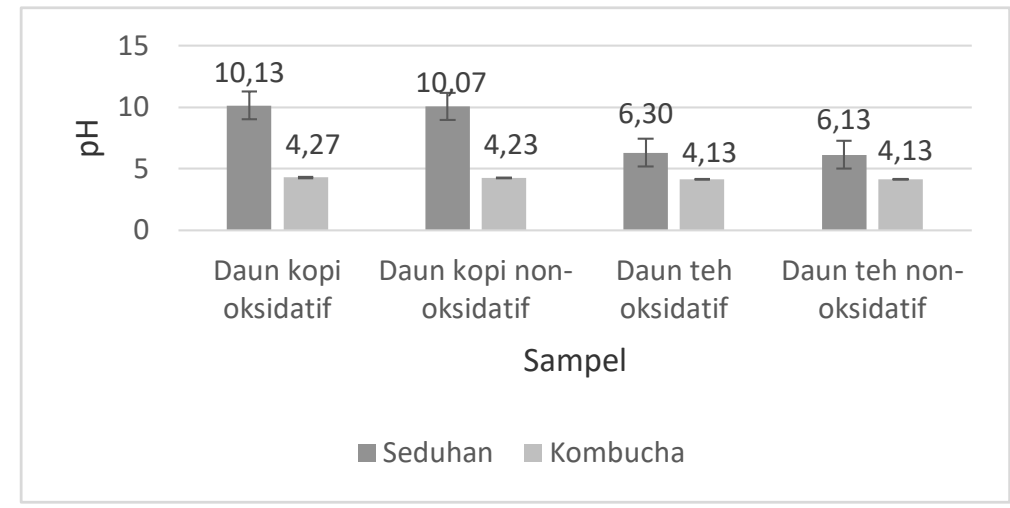

Gambar 6. Grafik Rerata Total Gula Seduhan dan Kombucha

Pada hasil analisis diketahui bahwa terjadi penurunan $\mathrm{pH}$ akibat adanya substrat gula yang berubah menjadi produk berupa alkohol dan asam organik. Penurunan $\mathrm{pH}$ kombucha disebabkan oleh asam-asam organik hasil metabolit bakteri dan khamir yang digunakan sebagai kultur semakin tinggi sehingga menghasilkan $\mathrm{pH}$ yang rendah. Menurut Greenwalt et al., (1998) menyatakan bahwa adanya aktivitas bakteri dapat membentuk asam-asam yang menyebabkan $\mathrm{pH}$ turun.

\subsection{Uji Warna}

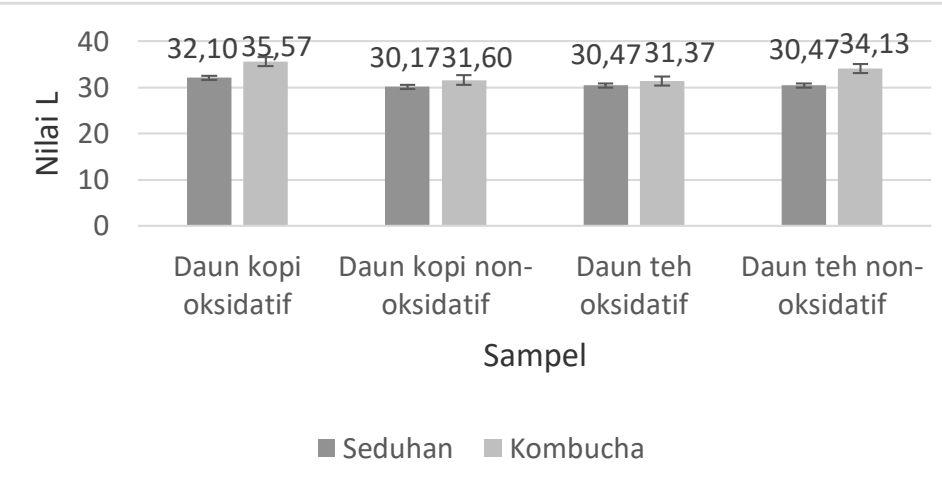

Gambar 7. Grafik Rerata Kecerahan $\left(L^{*}\right)$ Warna Seduhan dan Kombucha

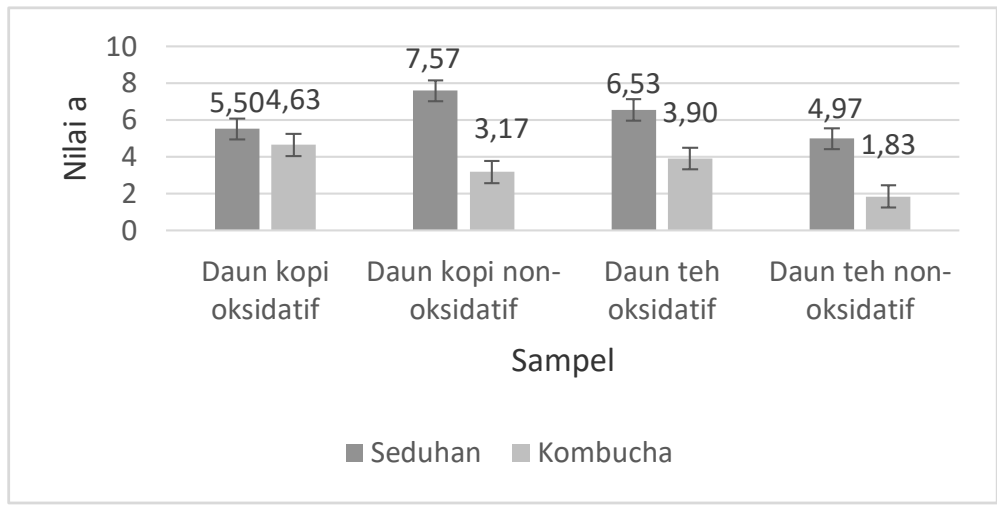

Gambar 8. Grafik Rerata Kemerahan (a*) Warna Seduhan dan Kombucha 


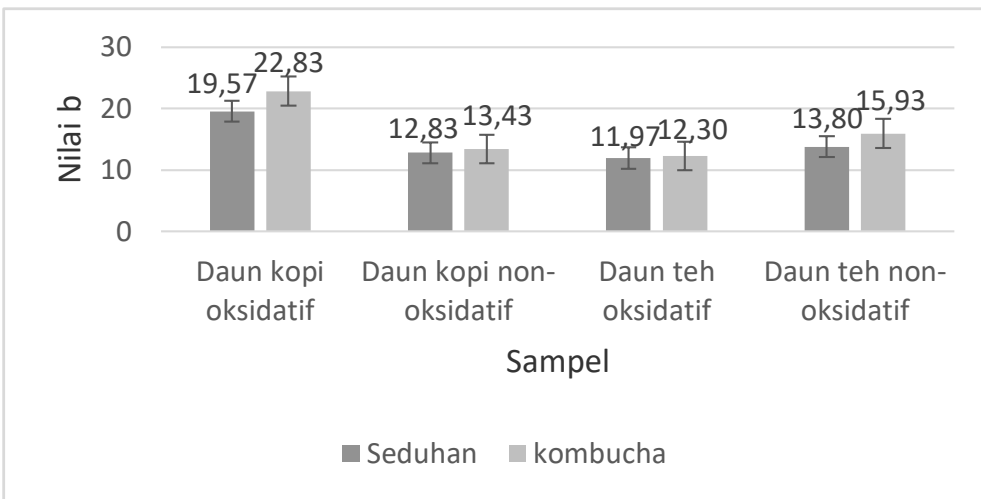

Gambar 9. Grafik Rerata Kekuningan ( $\left.b^{\star}\right)$ Warna Seduhan dan Kombucha

Berdasarkan hasil pengukuran warna tampak sedikit perubahan selama fermentasi, dimana nilai $\left(L^{*}\right)$ dan $\left(b^{*}\right)$ pada kombucha mengalami peningkatan dibanding nilai $\left(L^{*}\right)$ dan $\left(b^{*}\right)$ pada sampel seduhan. Nilai $L$ dan $b$ yang semakin tinggi menunjukkan bahwa sampel semakin cerah. Peningkatan nilai kekuningan $\left(b^{*}\right)$ berkaitan dengan kerusakan tanin karena adanya asam yang akan menyebabkan warna cerah (Anugrah, 2005). Berdasarkan hasil pengukuran menujukkan bahwa antara sampel seduhan dengan sampel kombucha terjadi penurunan nilai $\left(\mathrm{a}^{*}\right)$ yang menunjukkan tingkat kemerahan pada kombucha semakin menurun selama fermentasi. Hal ini disebabkan terbentuknya asam-asam yang menyebabkan penurunan $\mathrm{pH}$ dan warna coklat kemerahan tearubigin memudar (Wistiana, 2015).

\subsection{Uji Total Mikroba (TPC)}

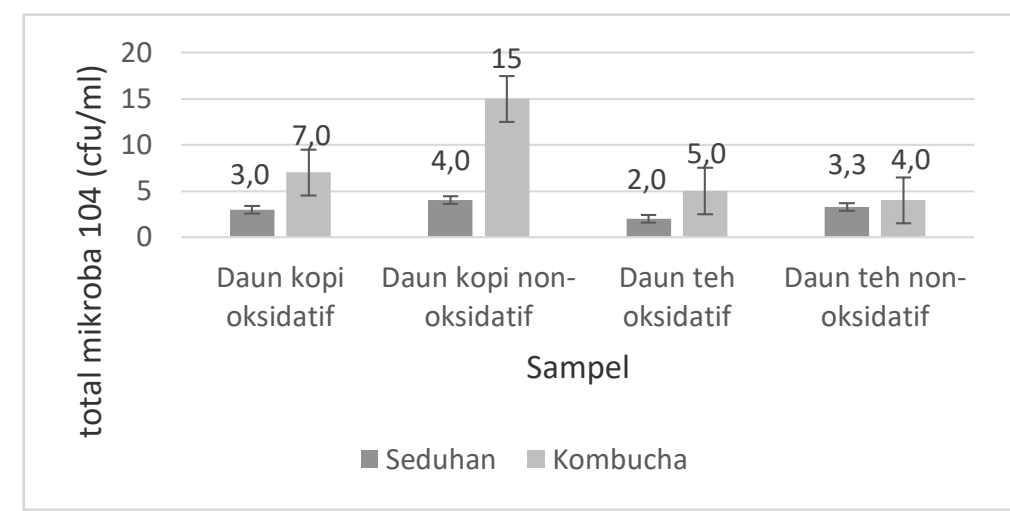

Gambar 10. Grafik Rerata Uji Total Mikroba Seduhan dan Kombucha

Hasil analisis total mikroba seduhan menjadi kombucha terjadi peningkatan disebabkan karena nutrisi yang tersedia dalam jumlah yang optimal untuk pertumbuhan Acetobacter xylinum yang akan memanfaatkan gula dalam pertumbuhannya. Menurut Aditiwati (2003), bahwa gula yang terdapat dalam media fermentasi kombucha akan dirombak oleh khamir menjadi alkohol dan dioksidasi oleh Acetobacter xylinum menjadi asam asetat dan asam organik lainnya, selain itu gula akan dirombak menghasilkan selulosa.

\section{Uji Organoleptik}

\subsection{Metode Rate-All-That-Apply}

Hasil analisis $p$-value atribut sensori sampel ini menunjukkan terdapat 7 atribut dari 19 atribut dengan $p$-value $<0.05$. Hal ini menunjukkan bahwa pada interaksi jenis daun dengan metode pengolahan daun menghasilkan 7 atribut yang menunjukkan perbedaan nyata yang dirasakan oleh panelis terhadap sampel kombucha teh daun kopi dan kombucha teh daun Camellia sinensis yang diolah dengan metode berbeda. Setelah diketahui hasil $p$-value, 
kemudian dilakukan uji lanjut pada masing-masing atribut yang menunjukkan nilai berbeda nyata $(\alpha<0.05)$ yaitu uji fisher. Uji lanjut dilakukan untuk mengetahui perbedaan antar jenis daun sebagai faktor mayor, serta antar metode pengolahan daun sebagai faktor minor pada masing-masing jenis daun.

4.1

\begin{tabular}{clc}
\multicolumn{2}{c}{ Tabel 4. Hasil Analisis P-value Atribut Sensori Sampel } \\
\hline No & Atribut & $P$-Value \\
\hline 1 & Warna kuning & $0.010^{*}$ \\
2 & Warna coklat & $0.000^{*}$ \\
3 & Warna hijau & 0.196 \\
4 & Rasa teh & 0.416 \\
5 & Rasa jeruk & 0.235 \\
6 & Rasa rerumputan & $0.008^{*}$ \\
7 & Rasa tanah & $0.001^{*}$ \\
8 & Rasa alkohol & 0.140 \\
9 & Rasa manis & 0.197 \\
10 & Rasa asam & 0.832 \\
11 & Rasa pahit & 0.096 \\
12 & Aroma teh & 0.054 \\
13 & Aroma jeruk & 0.199 \\
14 & Aroma rerumputan & $0.007^{\star}$ \\
15 & Aroma tanah & 0.229 \\
16 & Aroma alkohol & 0.363 \\
17 & Aroma manis & $0.002^{*}$ \\
18 & Aroma asam & 0.916 \\
19 & Aroma pahit & $0.000^{*}$ \\
\hline Keterangan: Tanda $\left(^{*}\right)$ menunjukkan nilai berbeda nyata $(\alpha<0.05)$ &
\end{tabular}

\subsection{Uji Hedonik}

Tabel 5. Hasil Uji Hedonik

\begin{tabular}{lc}
\hline \multicolumn{1}{c}{ Parameter } & Nilai $\boldsymbol{p}$-value \\
\hline Warna & 0.002 \\
Aroma & 0.002 \\
Rasa & 0.041 \\
Kenampakan & 0.001 \\
Keseluruhan & 0.018 \\
\hline
\end{tabular}

Hasil $p$-value uji hedonik menunjukkan perbedaan nyata yang dirasakan panelis terhadap semua parameter, yaitu warna, aroma, rasa, kenampakan, dan keseluruhan pada kombucha teh daun kopi dan kombucha teh daun Camellia sinensis.

\subsection{Uji Penerimaan}


Tabel 6. Hasil Uji Penerimaan

\begin{tabular}{ccc}
\hline Jenis Kombucha & Pengolahan Daun & P value \\
\hline Kombucha daun kopi & Oksidatif & 0.000 \\
Kombucha daun kopi & Non-oksidatif & 0.000 \\
Kombucha teh & Oksidatif & 0.000 \\
Kombucha teh & Non-oksidatif & 0.000 \\
\hline
\end{tabular}

Hasil uji penerimaan menunjukkan p-value pada semua sampel kombucha daun kopi dan daun teh Camellia sinensis baik metode pengolahan daun secara oksidatif maupun nonoksidatif sebesar 0.000 dimana p-value kurang dari 0.05 . Hal tersebut menunjukkan bahwa sampel dapat diterima lebih dari $50 \%$ panelis. Pada uji penerimaan ini berdasarkan hasil kesimpulan yang didapatkan melalui uji penerimaan menggunakan sensehub (Syahputra, 2018).

\section{SIMPULAN}

Hasil optimasi lama fermentasi menunjukkan bahwa lama fermentasi yang menghasilkan aktivitas antioksidan $\left(\mathrm{IC}_{50}\right)$ optimum yaitu 0 hari. Hasil pengujian karakteristik produk menunjukkan pada kombucha daun kopi yang diolah dengan metode oksidatif dan non-oksidatif memberikan pengaruh nyata terhadap aktivitas antioksidan $\left(\mathrm{IC}_{50}\right)$, total fenol, kadar tanin, total gula, dan nilai pH. Hasil uji organoleptik kombucha terhadap 19 atribut menunjukkan 7 atribut yang menunjukkan hasil yang berbeda nyata (warna kuning, warna coklat, rasa rerumputan, rasa tanah, aroma rerumputan, aroma manis, dan aroma pahit). Hasil uji hedonik menunjukkan perbedaan yang signifikan terhadap semua parameter (warna, aroma, rasa, kenampakan, dan keseluruhan). Hasil uji penerimaan menunjukkan bahwa kombucha teh daun kopi dengan dengan dengan metode oksidatif dan non-oksidatif dapat diterima oleh panelis.

\section{DAFTAR PUSTAKA}

Aditiwati, P dan Kusnadi. 2003. Kultur Campuran dan Faktor Lingkungan Mikroorganisme yang Berperan dalam Fermentasi Tea-Cider. Departemen Biologi Institut Teknologi Bandung. Bandung.

Agus, Martua I. 2012. Pengaruh Suhu dan Lama Waktu Ekstraksi Terhadap Sifat Kimia dan Fisik Pada Pembuatan Minuman Sari Jahe Merah dengan Kombinasi Penambahan Madu Sebagai Pemanis. Jurnal Pangan dan Agroindustri 3(2): 530-54.

Anugrah, S. T. 2005. Pengembangan Produk Kombucha Probiotik Berbahan Baku Teh Hitam (Camelia Sinensis). Institut Pertanian Bogor. Bogor

Apriyantono, A, Dedi Fardiaz, Ni Luh Puspitasari, Sedarnawati, Slamet Budiyanto. 1989. Petunjuk Laboratorium Analisis Pangan. Bogor. IPB.

Campa, C., \& Petitvallet, A. 2017. Beneficial Compounds From Coffee Leaves. In P. Lashermes (Ed.). Achieving sustainable cultivation of coffee. Cambridge: Burleigh Dodds Science Publishing Limited

FAO. 2015. World Tea Production and Trade: Current and Future Development. http://www.fao.org, diunduh pada tanggal 18 Desember 2018, pada pukul 10.15 WIB.

Greenwalt CJ, Ledford RA, Steinkraus KH. 1998. Determination and Characterization of The Antimicrobial Activity of The Fermented Tea Kombucha. Lebensm-Wiss. Technol. 31:291-296.

Heldman, Dennis. R. 2012. Food Procces Engineering Second Edition. The AVI Publishing Company, Inc. Wesport.

Khotimah, Khusnul. 2014. Karakteristik Kimia Kopi Kawa dari Berbagai Umur Helai Daun Kopi yang Diproses dengan Metode Berbeda. Jurnal Teknologi Pertanian 9(1):40-48. 
Nasution, Z. dan T. Wachyuddin. 1985. Pengolahan Teh. Agro Industri Press. Jurusan Teknologi Pertanian, FATETA, IPB. Bogor.

Pratama, N., U. Pato, dan Yusmarini. 2015. Kajian Pembuatan Teh Kombucha dari Kulit Buah Manggis (Garcinia mangostana L.). FAPERTA Vol. 2 No.2.

Rahayu dan Triastuti. 2007. Optimasi Fermentasi Cairan Kopi Dengan Inokulan Kultur Kombucha (Kombucha Coffee). Jurnal Penelitian Science dan Teknologi, 8(1) : 15-29.

Rohdiana, D. 2007. Petunjuk Teknis Pengolahan Teh. Pusat Penelitian Teh dan Kina. Gambung.

Syahputra, M. A. 2018. SenseHub: Aplikasi Web Terintegrasi untuk Analisis Sensori. https://doi.org/10.17605/OSF.IO/9GZRN

Walter, M and Marchesen E. 2011. Phenolic Compouds and Antioxidant Activity of Rice. Brazilian Archives of Biology and Technology.An Internasional Journal. 54 (1): pp. 371 377.

Wijana, S., Sucipto, dan M. Wulandari. 2017. Formulasi Teh Celup Fungsional, Pengaruh Jenis Teh (Hitam dan Hijau) Dan Penambahan Bubuk Kulit Buah Manggis. Prosiding Seminar Nasional FKPT-TPI 2017.

Winarno, F.G. 1997. Food Chemistry and Nutrition. Gramedia. Jakarta.

Wistiana, Duwi dan Zubaidah, Elok. 2015. Karakteristik Kimiawi dan Mikrobiologis Kombucha dari Berbagai Daun Tinggi Fenol Selama Fermentasi. Jurnal Pangan dan Agroindustri Vol. 3 No 4 p. 1446-1457. Universitas Brawijaya, Malang. 